\title{
INFLUENCE OF ADDING LINSEED OR SUNFLOWER OILS TO DIETS ON THE PERFORMANCE OF BROILER CHICKS
}

\author{
A. A. EL- Fiky, G. A. Zanaty, Manal K. Abou El - Naga \\ and M. A. B. Madein \\ Poult. And Fish Prod. Dept, Fac. of Agric., Menoufia Univ., Shebin El-Kom, Egypt.
}

Received: Sep. 20,2020

Accepted: Oct. 26,2020

\begin{abstract}
The present study was carried out in a private commercial broilers farm at Berket EL-Saab city, Menoufia governorate, Egypt, during the period from May to June 2019. The aim of this study was to investigate the impacts of adding two vegetable oils, linseed or sunflower, in broiler diets, on growth performance, some blood components, some carcass traits, immunity and economic efficiency. A total number of one hundred and eighty, one day old unsexed Arbor Acres broiler chicks were used in this study. Chicks were individually weighed, wing banded and randomly assigned to three treatments $\left(T_{1}, T_{2}\right.$ and $\left.T_{3}\right), 3$ replicates pens of 20 birds each nearly similar in average body weight $(\mathbf{4 2 g})$. Two vegetable oils, linseed or sunflower, were added at the level of $3 \%$ in broiler diets. The experimental groups were as follows: $T_{1}$ : Control (basal diet without oil), $T_{2}$ : basal diet with $3 \%$ linseed oil and $T_{3}$ : basal diet with $3 \%$ sunflower oil. Results revealed that body weight, body weight gain, feed conversion ratio and performance index were significantly improved $(P \leq 0.05)$ with the addition of vegetable oils from 1 - 35 days of age compared to the control birds. Birds fed linseed oil had higher values of white blood cells (WBCs), total cholesterol, triglyceride and high density lipo-protein (HDL), while low density lipo-protein (LDL) was the lowest value compared to the other groups. Linseed or sunflower oils addition significantly and liver \%, while dressing percentage, heart and gizzard \% were not affected. Immune organs proportion (spleen, thymus and bursa \%) were significantly $(P \leq 0.05)$ increased when birds received linseed oil supplement compared to birds fed sunflower oil supplement or basal diet (control). Chicks fed linseed oil treatment recorded the highest relative economic efficiency (108.20\%), followed by chicks fed sunflower oil (103.28), considering the control group as $100 \%$.
\end{abstract}

It could be concluded that supplementation of $3 \%$ linseed oil to the broiler diets can be used with no adverse effects, and with improving body weight, feed conversion ratio, performance index and increasing the proportion of immune organs and relative economical efficiency.

Key words: Broilers, linseed oil, sunflower oil, growth performance, blood components and immunity.

\section{INTRODUCTION}

In broiler chickens production, feed represents a major proportion of production costs. Van der Klis et al. (2010) demonstrated that, energy accounts for $70-75 \%$ of feed costs. In the past, cereal grains have been the major source of energy in broiler diets, however, dietary fats have also been used more recently as high energy components. Amount of fatty acid in the chicken meat depend on the feed provided to the chicken. Several studies suggest that in both birds and mammals, polyunsaturated fatty acids (PUFA) inhibit lipid synthesis (Simopoulos, 2009 and Nguyen et al., 2003). Flaxseed is unique among oilseeds because of its 
exceptionally high content of $\alpha$-linolenic acid $(18: 3, n-3)$, contains 35 to $45 \%$ oil (Bhatty, 1995). In mono gastric species such as poultry, the fatty acid profile of the meat and fat is directly affected by the source of fat in diet. It has been reported that feeding omega-3 enriched diets to poultry increases the omega-3 content of eggs and meat and thus enriched poultry products offer consumers an alternative to enhance their omega-3 daily intake (Lopez-Ferrer et al., 2001).

There is increasing recognition of the health benefits of PUFA in general, and of n3 fatty acids in particular, because these fatty acids are essential for humans. Today we know that $\mathrm{n} 3$ fatty acids are important in the prevention and treatment of coronary disease, hypertension, diabetes and arthritis.

Several trials have shown that an increase in the content of long chain n3 PUFA in chicken broiler meat may be achieved by including linseed oil as a source of precursor and $\alpha$-linolenic acid.

Dietary oils have high caloric value and thus provide increased energy levels at a lower cost (Baiao and Lara, 2005). In addition, oil improves the absorption of oil-soluble vitamins, increases the palatability of rations, reduces pulverulence, increases the efficiency of the consumed energy (Baiao and Lara, 2005 and Chwen et al., 2013) and also reduces the rate of passage of digesta in the gastrointestinal tract, which gives room for adequate and efficient absorption of the nutrients present in such diet (Baiao and Lara, 2005).

It was observed that the replace of tallow by vegetable fats rich in polyunsaturated fatty acids like sunflower oil, soybean oil or linseed oil resulted in decreasing the abdominal fat deposition in broilers (Wongsuthavas et al., 2008).
Therefore, the aim of this experiment was to study the effect of adding two vegetable oils, linseed or sunflower oils in broiler diets on growth performance, some carcass traits, some blood components, immunity and economic efficiency.

\section{MATERIALS AND METHODS}

This work was carried out in a private commercial broilers farm at Berket ELSaab city, Menoufia governorate, Egypt, throughout the experimental period from (May to June 2019). The aim of this study was to investigate the impact of adding two vegetable oils, linseed or sunflower in broiler diets, on growth performance, some carcass traits, some blood components, immunity and economic efficiency.

One hundred and eighty, one day old un sexed Arbor Acres broiler chicks were used in this study. Chicks were wing banded, individually weighed and randomly assigned to three treatments $\left(T_{1}, T_{2}\right.$ and $\left.T_{3}\right)$, in 3 replicates pens of 20 birds nearly similar in average body weight $42 \mathrm{~g}$ Two vegetable oils, linseed or sunflower, were added at the level of $3 \%$ in broiler diets. Birds received their diets to save the nutrient requirements according to the NRC (1994) recommendations. Artificial light was used to provide 24 hours photo period. Vaccination and medical program were done according to common veteranian care practice. Chicks housed on floor furnished with wheat straw.

The composition and chemical analysis of the experimental diets are shown in (Table 1). Feed and water were provided ad-libitum during the experimental period ( 1 - $35 d$ of age). Diets were formulated to be isonitrogenous, isocaloric and covered nutrient requirements for birds throughout starting (1- 21) and growing (22 - 35) periods of age according to NRC (1994) 
recommendations. The experimental groups were as follows: $T_{1}$ : Control (basal diet without oil), $\mathrm{T}_{2}$ : basal diet with $3 \%$ linseed oil and $\mathrm{T}_{3}$ : basal diet with $3 \%$ sunflower oil. Body weight (BW), body weight gain (BWG) and feed intake (FI) was recorded weekly. Feed conversion ratio (FCR) was calculated during the experimental period. At the end of the experimental ( 5 weeks of age), 6 birds from each treatment around the average live body weight were chosen, fasted for about 12 hours, weighed and slaughtered to complete bleeding, followed by blucking the feathers. Dressing and giblets weight were expressed related to live body weight and recorded. Blood samples were collected into tubes without heparin and separated by centrifugation at $\mathbf{3 0 0 0} \mathrm{rpm}$ for 15 minutes and frozen at $-20 \mathrm{C}^{\circ}$ until analysis. as well as white blood cells (WBCs) were counted; and their types cells were also determined according to Feldman et al. (2000). concentration and packed cells volume percentages (PCV) were measured according to Drew et al. (2004). Also, Serum total cholesterol, Triglyceride concentration, High density lipoprotein and low density lipoprotein was determined using commercial kits. The economic efficiency of the experimental diets used in the present study was calculated from the input output analysis (Heady and Jensen, 1954), assuming that the other head costs were constant.

Table 1. Composition and calculated analysis of the experimental diets fed during starting $(1-21)$ and growing periods $(22-35)$ days of age.

\begin{tabular}{|c|c|c|c|c|c|c|}
\hline \multirow[b]{2}{*}{ Ingredients } & \multicolumn{3}{|c|}{ Starter diets } & \multicolumn{3}{|c|}{ Grower diets } \\
\hline & $T_{1}$ & $T_{2}$ & $\mathbf{T}_{3}$ & $T_{1}$ & $T_{2}$ & $T_{3}$ \\
\hline Ground yellow corn, $8.5 \%$. & 58.30 & 52.70 & 52.70 & 64.50 & 59.30 & 59.30 \\
\hline Soybean meal, $44 \%$. & 30.40 & 32.55 & 32.55 & 30.16 & 31.00 & 31.00 \\
\hline Corn gluten meal, $62 \%$. & 7.80 & 6.70 & 6.70 & 2.10 & 1.90 & 1.90 \\
\hline Wheat bran, \%. & ------ & 1.26 & 1.26 & ------ & 1.42 & 1.42 \\
\hline Linseed oil, \%. & ------ & 3.00 & ------ & ----- & 3.00 & ------ \\
\hline Sunflower oil, \%. & ------ & ------ & 3.00 & ----- & ------ & 3.00 \\
\hline Limestone, \%. & 1.50 & 1.45 & 1.45 & 1.64 & 1.57 & 1.57 \\
\hline Di- calcium phosphate, \%. & 1.35 & 1.69 & 1.69 & 0.95 & 1.16 & 1.16 \\
\hline Salt (Sodium chloride), \%. & 0.25 & 0.25 & 0.25 & 0.25 & 0.25 & 0.25 \\
\hline Vit. and min.mixture ${ }^{1}, \%$. & 0.30 & 0.30 & 0.30 & 0.30 & 0.30 & 0.30 \\
\hline DL- Methionine ${ }^{2}, \%$. & 0.10 & 0.10 & 0.10 & 0.10 & 0.10 & 0.10 \\
\hline Total & 100 & 100 & 100 & 100 & 100 & 100 \\
\hline \multicolumn{7}{|c|}{ Calculated analysis (air dry basis) ${ }^{3}}$. \\
\hline Crude protein, \%. & 23.01 & 23.01 & 23.01 & 20.01 & 20.01 & 20.01 \\
\hline ME, $\mathrm{K}$ cal/Kg diet. & 3020 & 3018 & 3018 & 3017 & 3018 & 3018 \\
\hline C/P ratio. & 131 & 131 & 131 & 151 & 151 & 151 \\
\hline Calcium, \%. & 0.98 & 1.01 & 1.01 & 0.97 & 0.98 & 0.98 \\
\hline Available Phosphorus, \%. & 0.45 & 0.46 & 0.46 & 0.45 & 0.46 & 0.46 \\
\hline
\end{tabular}

${ }^{1}$ Vitamins and minerals mixture at $0.30 \%$ of the diet supplies the following/ $\mathrm{kg}$ of the diet: Vit. A, 12000 IU; Vit. $D_{3}, 2500 \mathrm{IU}$; Vit. E, $10 \mathrm{mg}$; Vit. $K_{3}, 3 \mathrm{mg}$; Vit $B_{1}, 1 \mathrm{mg}$; Vit. $B_{2}, 4 \mathrm{mg}$; Pantothenic acid, $10 \mathrm{mg}$ 
;Nicotinic acid, $20 \mathrm{mg}$; Folic acid, $1 \mathrm{mg}$; Biotin, $0.05 \mathrm{mg}$; Niacin, $40 \mathrm{mg}$; Vit.B 6 , 3 mg; Vit B $12,0.02$ mg; Choline chloride, 400 mg; Mn, 62 mg; Fe, 44 mg; Zn, 56 mg; I, 1 mg; Cu, 5 mg and Se, 0.01 mg.

${ }^{2} \mathrm{DL}$ - Methionine: $98 \%$ feed grade (98\% Methionine).

${ }^{3}$ Calculated according to NRC (1994).

Statistical Analysis:

Data were statistically analyzed by the completely randomized design using SPSS (2011) program and the differences among means were determined using Duncan's multiple range test (Duncan, 1955). Percentages were transformed to the corresponding arcsine values before performing statistical analysis (Snedecor and Cochran, 1982).

The model applied was:

$Y_{i j}=\mu+\alpha i+E i j$, Where:- $Y i j=$ an observation. $\mu=$ Overall mean. $\alpha i=$ effect of treatment $(I=1,2$ and 3$)$, and $E i j=$ Random error.

\section{RESULTS AND DISCUSSIONS}

\section{Growth performance:}

Table 2 showed that adding linseed or sunflower oils significantly $(P \leq 0.05)$ increased body weight (BW) and body weight gain (BWG) at 3 and 5 weeks of age compared to the control group $\left(T_{1}\right)$ and the linseed achieved the heaviest BW and BWG $\left(T_{2}\right)$. Also, performance index (PI) was significantly $(P \leq 0.05)$ increased by adding vegetable oils (linseed or sunflower) at 3 and 5 weeks of age compared to the control group $\left(\mathrm{T}_{1}\right)$. The highest (PI) was in linseed oil group $\left(\mathrm{T}_{2}\right)$ which recorded 72.05 and $146.02 \%$ at 3 and 5 weeks of age, respectively compared to birds fed sunflower oil $\left(\mathrm{T}_{3}\right)$ which recorded 58.88 and $95.21 \%$, respectively, whereas the lower PI (44.54 and $79.24 \%$ ) was in the control group.

These findings are supported with those obtained by Duarte et al. (2013) who found that body weight gain was significantly higher in broilers fed linseed oil at levels of 6.6 and $9.9 \%$ which recorded $2764 \mathrm{~g}$ and $2805 \mathrm{~g}$ compared to broilers fed control diet without linseed oil which recorded $2532 \mathrm{~g}$.

On the other hand, El katcha et al. (2014), Masek et al. (2014), and Febal et al. (2008) observed that feeding soybean or linseed oils did not increased body weight or body weight gain. Also, Starčević et al. (2014) showed that growth performance of chickens was not significantly differ between groups fed linseed or sunflower oils.

Table 2. Effect of dietary linseed or sunflower oils ( $X \pm S E$ ) on the performance of growing broiler chicks at 3 and 5 weeks of age.

\begin{tabular}{|c|c|c|c|c|c|c|}
\hline \multirow{2}{*}{ Treatments $^{1}$} & \multicolumn{2}{|c|}{ Body weight (g) } & \multicolumn{2}{|c|}{ Body weight gain (g) } & \multicolumn{2}{|c|}{$\begin{array}{l}\text { Performance } \\
\text { Index (PI, \%) }\end{array}$} \\
\hline & 3 weeks & 5 weeks & 3 weeks & 5 weeks & 3 weeks & 5 weeks \\
\hline $\mathrm{T}_{1}$ & $574.60^{c} \pm 0.81$ & $1680^{c} \pm 0.002$ & $301.40^{c} \pm 0.111$ & $620.00^{c} \pm 0.120$ & $44.54^{c} \pm 0.12$ & $79.24^{2,3 c} \pm 0.17$ \\
\hline $\mathrm{T}_{2}$ & $864.60^{\mathrm{a}} \pm 0.81$ & $2205^{\mathrm{a}} \pm 0.002$ & $427.00^{\mathrm{a}} \pm 0.111$ & $685.00^{\mathrm{a}} \pm 0.120$ & $72.05^{a} \pm 0.12$ & $146.02^{\mathrm{a}} \pm 0.17$ \\
\hline $\mathbf{T}_{3}$ & $736^{b} \pm 0.81$ & $1952^{b} \pm 0.002$ & $392.40^{\mathrm{b}} \pm 0.111$ & $652.00^{b} \pm 0.120$ & $58.88^{b} \pm 0.12$ & $95.21^{b} \pm 0.17$ \\
\hline
\end{tabular}

\footnotetext{
${ }^{1} \mathrm{~T}_{1}$; Control diet, $\mathrm{T}_{2}$; Control diet $+3 \%$ Linseed oil and $\mathrm{T}_{3}$; Control diet $+3 \%$ Sunflower oil.
} 
${ }^{2} \mathrm{X} \pm \mathrm{SE}$ of 3 replicates / treatment.

3 a,b,c....: Means within the same row with different superscripts are significantly different $(P \leq 0.05)$.

${ }^{4}$ Performance Index (PI, \%) = Live body weight, $\mathrm{Kg} \times 100 /$ feed conversion ratio.

\section{Feed intake and feed conversion ratio:}

Data in Table (3) showed that the addition of linseed $\left(T_{2}\right)$ or sunflower $\left(T_{3}\right)$ oils in diets had significantly $(P \leq 0.05)$ increased daily feed intake at 3 and 5 weeks of age. The highest daily feed intake was recorded in linseed oil group (73.20 and $192.78 \mathrm{~g} / \mathrm{bird} / \mathrm{day}$ ) then birds fed sunflower oil (70.08 and $190.94 \mathrm{~g} /$ bird/ day) and the last one was the control group $\left(\mathrm{T}_{1}\right)$ which recorded $\mathbf{5 5 . 5 5}$ and $187.77 \mathrm{~g} / \mathrm{bird} / \mathrm{day}$, respectively at 3 and 5 weeks of age. The best feed conversion ratio was in $T_{2}$ which recorded 1.20 and 1.97 at 3 and 5 weeks of age then birds fed sunflower oil (1.25 and 2.05) and the worest value was the control group $\left(T_{1}\right)$ which recorded 1.29 and 2.12 at same ages (Table 3 ).

Wenying et al., 2019, concluded that adding $5 \%$ of flax oil to the standard corn-soybean meal diet improved feed efficiency ratio of growing broilers. Also, Rahimi et al. (2011) indicted that increasing dietary linseed oil or canola oil had a significant effect on feed conversion ratio.

On the other hand, Houguo et al.
(2015) observed that linseed oil or soybean oil supplementation did not reduce the feed efficiency ratio.

\section{Blood components:}

Table (4) showed that adding linseed $\left(T_{2}\right)$ or sunflower $\left(T_{3}\right)$ oils have significantly $(P \leq 0.05)$ increased cholesterol value at 5 weeks of ages. The highest was recorded in broilers fed linseed oil $(130.55 \mathrm{mg} / \mathrm{dl})$ then broilers fed sunflower oil $(127.11 \mathrm{mg} / \mathrm{dl})$ and the last one was in the control which recorded $(125.80 \mathrm{mg} / \mathrm{dl})$ and the higher triglyceride was found in broilers fed diet supplemented with linseed or sunflower oils in diets which recorded $110.22 \mathrm{mg} / \mathrm{dl}$ and $10.90 \mathrm{mg} / \mathrm{dl}$ respectively. The lowest value of triglyceride was in control group which recorded $108.70 \mathrm{mg} / \mathrm{dl}$. The highest HDL was recorded in broilers fed $3 \%$ linseed oil in diets $(75.80 \mathrm{mg} / \mathrm{dl})$ then broilers fed $3 \%$ sunflower oils $(70.43$ $\mathrm{mg} / \mathrm{dl}$ ) and the lowest value was in the control which recorded $70.40 \mathrm{mg} / \mathrm{dl}$. Broilers fed $3 \%$ sunflower oil and those in the control group have the highest LDL which recorded 34.70 and $33.66 \mathrm{mg} / \mathrm{dl}$, respectively.

Table 3. Effect of dietary linseed or sunflower oils ( $X \pm S E$ ) on daily feed intake and feed conversion ratio* at 3 and 5 weeks at 5 weeks of broiler chicks of age.

\begin{tabular}{ccccc}
\hline \multirow{2}{*}{ Treatments $^{1}$} & \multicolumn{2}{c}{ Feed intake $(\mathrm{g} /$ bird/ day) } & \multicolumn{2}{c}{$\begin{array}{c}\text { Feed } \\
\text { conversion ratio* }\end{array}$} \\
\cline { 2 - 5 } & 3 weeks & 5 weeks & 3 weeks & 5 weeks \\
\cline { 2 - 5 } $\mathrm{T}_{1}$ & $55.55^{\mathrm{c}} \pm 0.43$ & $187.77^{\mathrm{c}} \pm 1.78$ & $1.29^{\mathrm{a}} \pm 0.79$ & $2.12^{2,3 \mathrm{a}} \pm 0.57$ \\
$\mathrm{~T}_{2}$ & $73.20^{\mathrm{a}} \pm 0.43$ & $192.78^{\mathrm{a}} \pm 3.21$ & $1.20^{\mathrm{c}} \pm 0.79$ & $1.97^{\mathrm{c}} \pm 0.57$ \\
$\mathrm{~T}_{3}$ & $70.08^{\mathrm{b}} \pm 0.33$ & $190.94^{\mathrm{b}} \pm 1.74$ & $1.25^{\mathrm{b}} \pm 0.79$ & $2.05^{\mathrm{b}} \pm 0.57$ \\
\hline
\end{tabular}


A. A. EL-Fiky, et al.,

SIG

*

${ }^{1} \mathrm{~T}_{1}$; Control diet, $\mathrm{T}_{2}$;Control diet $+3 \%$ Linseed oil and $\mathrm{T}_{3}$; Control diet $+3 \%$ Sunflower oil.

${ }^{2} \mathrm{X} \pm \mathrm{SE}$ of 3 replicates / treatment.

${ }^{3}$ a,b,c...: Means within the same row with different superscripts are significantly different $(P \leq 0.05)$.

* Feed conversion ratio= (feed intake, $\mathbf{g} / \mathrm{d}$ )/ (body weight gain, $\mathbf{g} / \mathrm{d}$ ).

Table 4. Effect of dietary linseed or sunflower oils ( $X \pm S E$ ) on some blood components at 5 weeks of age.

\begin{tabular}{ccccc}
\hline & $\begin{array}{c}\text { Total } \\
\text { cholesterol }\end{array}$ & Triglyceride & HDL & LDL \\
\cline { 2 - 5 } & $-125.80^{\mathrm{c}} \pm 3.84$ & $108.70^{\mathrm{b}} \pm 2.85$ & $70.40^{\mathrm{b}} \pm 3.16$ & $33.66^{\mathrm{a}} \pm 1.00$ \\
\hline $\mathrm{T}_{1}$ & $130.55^{\mathrm{a}} \pm 3.20$ & $110.22^{\mathrm{a}} \pm 2.91$ & $75.80^{\mathrm{a}} \pm 3.16$ & $32.70^{\mathrm{b}} \pm 1.00$ \\
$\mathrm{~T}_{2}$ & $127.11^{\mathrm{b}} \pm 3.15$ & $109.90^{\mathrm{a}} \pm 2.89$ & $70.43^{\mathrm{b}} \pm 3.16$ & $34.70^{\mathrm{a}} \pm 1.00$ \\
$\mathrm{~T}_{3}$ & $*$ & $*$ & $*$ & $*$ \\
\hline SIG & & $*$ & $*$
\end{tabular}

${ }^{1} \mathrm{~T}_{1}$; Control diet, $\mathrm{T}_{2}$;Control diet $+3 \%$ Linseed oil and $\mathrm{T}_{3}$; Control diet $+3 \%$ Sunflower oil.

${ }^{2} \mathrm{X} \pm \mathrm{SE}$ of 3 replicates / treatment.

${ }^{3} a, b, c . . .:$ Means within the same row with different superscripts are significantly different $(P \leq 0.05)$.

These results are coincides with Malwina et al. (2020) who reported that some blood parameters influenced by the flaxseed supplementation, e.g, the level of hemoglobin declined $(P \leq 0.05)$ and the iron level in plasma increased $(P \leq 0.05)$ and they concluded that, flax and sunflower oils can be regarded as good dietary components with positive effects on the dietary value of poultry meat.

\section{Carcass characteristics:}

The effect of dietary linseed $\left(T_{2}\right)$ or sunflower $\left(T_{3}\right)$ oils on carcass characteristics of growing broilers at 5 weeks of age is presented in Table (5). There were no significant differences between treatments on all observed carcass characteristics, but liver percentage (\%) had significantly decreased.
These results were in agreement with Panda et al. (2015) who found that carcass parameters such as dressing, heart and gizzard \% were not affected due to dietary incorporation with linseed oil. The abdominal fat content was significantly reduced by dietary incorporation of linseed oil in broiler's diets.

\section{Immune organs:}

Results of some immune organs at 5 weeks of age are presented in Table (6). Immune organs percentage (spleen, thymus, and bursa) were significantly affected by the supplementation of linseed oils $(3 \%)$ and recorded the highest values $(0.24,1.04$ and $0.22 \%)$, respectively compared to chicks fed the control diet or diet supplemented with 3 $\%$ sunflower oil which recorded the lowest value and almost the same values. 
These results are in agreement with Wenying et al. (2019) who concluded that adding $5 \%$ of flax oil to the standard corn
- soybean meal diet affected the $T$ lymphocyte ratio of fast growing broilers.

Table 5. Effect of dietary linseed or sunflower oils ( $X \pm S E$ ) on carcass characteristics of growing broiler chicks at 5 weeks of age.

\begin{tabular}{|c|c|c|c|c|}
\hline \multirow{3}{*}{ Treatments $^{1}$} & \multicolumn{4}{|c|}{ Carcass traits (\%) } \\
\hline & \multirow{2}{*}{$\begin{array}{c}\text { Dressing }^{*} \\
\text { Giblets }\end{array}$} & \multicolumn{3}{|c|}{ Giblets } \\
\hline & & Liver & Heart & Gizzard \\
\hline $\mathrm{T}_{1}$ & $75.9 \pm 1.23$ & $2.78^{2.3 a} \pm 0.01$ & $0.42 \pm 0.03$ & $2.22 \pm 0.12$ \\
\hline $\mathrm{T}_{2}$ & $75.9 \pm 1.18$ & $2.59^{b} \pm 0.03$ & $0.46 \pm 0.05$ & $2.26 \pm 0.16$ \\
\hline$T_{3}$ & $75.9 \pm 1.20$ & $2.56^{b} \pm 0.05$ & $0.44 \pm 0.04$ & $2.24 \pm 0.15$ \\
\hline SIG & NS & * & NS & NS \\
\hline \multicolumn{5}{|c|}{ 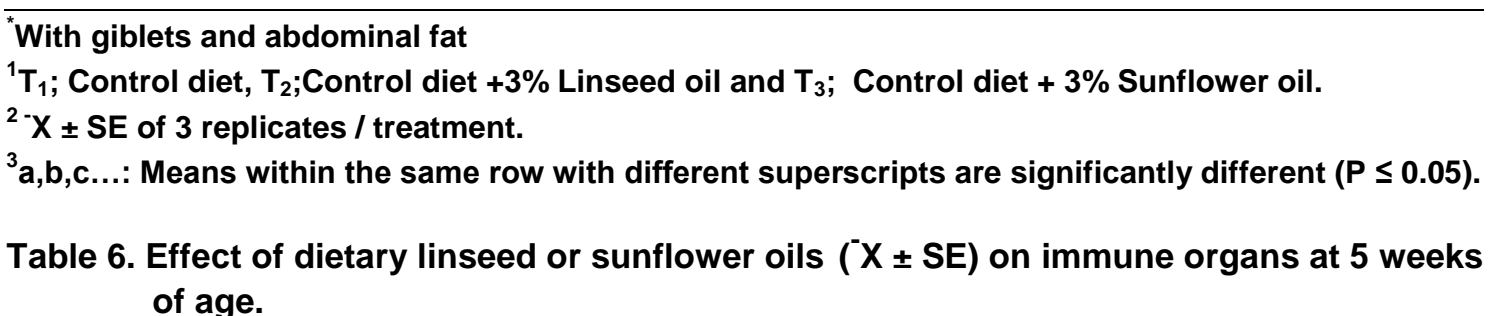 } \\
\hline
\end{tabular}

Treatments $^{1}$

Immune organs (\%)

\begin{tabular}{cccc} 
& Spleen $\%$ & Thymus $\%$ & Bursa\% \\
\cline { 2 - 4 } $\mathrm{T}_{1}$ & $0.18^{\mathrm{b}} \pm 0.02$ & $0.82^{\mathrm{b}} \pm 2.4$ & $0.14^{2,3 \mathrm{~b}} \pm 0.01$ \\
$\mathrm{~T}_{2}$ & $0.24^{\mathrm{a}} \pm 0.02$ & $1.04^{\mathrm{a}} \pm 2.4$ & $0.22^{\mathrm{a}} \pm 0.01$ \\
$\mathrm{~T}_{3}$ & $0.16^{\mathrm{b}} \pm 0.02$ & $0.88^{\mathrm{b}} \pm 2.4$ & $0.13^{\mathrm{b}} \pm 0.01$ \\
\hline SIG & $*$ & $*$ & $*$
\end{tabular}

${ }^{1} \mathrm{~T}_{1}$; Control diet, $\mathrm{T}_{2}$; Control diet $+3 \%$ Linseed oil and $\mathrm{T}_{3}$; Control diet $+3 \%$ Sunflower oil.

${ }^{2} \mathrm{X} \pm \mathrm{SE}$ of 3 replicates / treatment.

${ }^{3}$ a,b,c...: Means within the same row with different superscripts are significantly different $(P \leq 0.05)$.

\section{Economic efficiency:}

Results of feeding cost for chicks fed the experimental diets are presented in Table (7). The relative economical efficiency measures the differences between the income of the business and the cost of the feed and is a product of meat production and marketing price. 
Production volume is influenced by feed price, feed intake, final body weight and marketing price. Through our inputs and outcomes for 35 days old broilers chicks, relative economical efficiency was increased with the addition of $3 \%$ linseed oil (108.20 and net revenue 28.85 L.E.) or $3 \%$ sunflower oil ( 103.28 and net revenue 24.99 L.E.) compared to 21.21 L.E. in the control group.

Table 7. Effect of dietary linseed or sunflower oils on the economic efficiency of the experimental diets at 35 days.

\begin{tabular}{lccc}
\hline \multirow{2}{*}{ Items } & \multicolumn{3}{c}{ Dietary treatments $^{1}$} \\
\cline { 2 - 4 } & $\mathrm{T}_{1}$ & $\mathrm{~T}_{2}$ & $\mathrm{~T}_{3}$ \\
\hline Initial body weight, g. & 40.60 & 42.60 & 42.00 \\
Final body weight, kg. & 1.68 & 2.20 & 1.95 \\
Body weight gain, kg. & 1.64 & 2.16 & 1.91 \\
Total revenue2, L. E. & 38.54 & 50.76 & 44.89 \\
Feed intake, kg. & 2.75 & 3.37 & 3.11 \\
Price of one kg feed, L. E. & 6.30 & 6.50 & 6.40 \\
Feed cost, L. E3. & 17.33 & 21.91 & 19.90 \\
Net revenue4, L. E. & 21.21 & 28.85 & 24.99 \\
Economical efficiency5. & 1.22 & 1.32 & 1.26 \\
Relative economic efficiency, \%(REE)6. & 100 & 108.20 & 103.28
\end{tabular}

Price of one $\mathrm{kg}$ live body weight was 23.5 L.E.

${ }^{1} \mathbf{T}_{1}$; Control, $\mathrm{T}_{2}$; Linseed oil $3 \%$, and $\mathrm{T}_{3}$; Sunflower oil $3 \%$.

${ }^{2}$ Total revenue $=$ body weight gain $\times$ marketing price which is 23.5 L.E. $\mathrm{kg}$ at time of experiment.

${ }^{3}$ feed cost $=$ feed intake $x$ price of $\mathrm{kg}$ of diet

${ }^{4}$ Net revenue $=$ Total revenue - Feed cost.

${ }^{5}$ Economical efficiency $=$ Net revenue $/$ Feed cost.

${ }^{6} \mathrm{REE}$ (Relative economic efficiency); assuming that economic efficiency of control group equal100

\section{CONCLUSION:}

In general, based on the obtained experimental results reported in this study, it could be concluded that the supplementation of $3 \%$ linseed oil to the broiler diets can be used with no adverse effects. It will act improving body weight, feed conversion ratio, performance index, increasing the proportion of immune organs and relative economical efficiency, under the same conditions of this study.

\section{REFERENCES}

Baiao, N. C and L. Lara (2005). Oil and fat in broiler nutrition. Rev Bras de Ciência Avícola. 7:129 - 141.

Bhatty, R. S. (1995). Nutrient composition of whole flaxseed and flaxseed meal. Flaxseed in Human Nutrition; 22 - 42. 
Chwen, L. T., H. L. Foo, N. T. Thanh and D. Choe (2013). Growth performance, plasma fatty acids, villous height and crypt depth of preweaning piglets fed with medium chain Triacylglycerol. Asian Austral J. Anim. Sci., 26:700 704.

Drew, P., R. J. S. Charles, B. Trevor and L. John (2004). Oxford Handbook of Clinical Haematology.2th Edition, Oxford University Press, USA.

Duarte, K. F., O. M. Junqueirall, L. L. Borges, A. C. Rodrigues, C. H. Laurentiz and de. F. Domingues (2013). Performance, carcass traits and body composition of broilers fed different linseed oil levels between 21 and 56 days of age. Braz J. Poul. Sci., $15(4)$ : $\quad 55-60$.

Duncan, D. B (1955). Multiple Range and Multiple F Tests. Biometrics, Vol. 11, No. 1, pp. 1 - 42.

El-Katcha, M., M. E. El-Kholy, M. A. Soltan and A. H. EL-Gayar (2014). Effect of dietary omega-3 to omega- 6 ratio on growth performance, immune response, carcass traits and meat fatty acids profile of broiler chickens. Poul. Sci. J. 2014, 2 (2): 71 - 94.

Febal, H., M. Mezes and T. Pálfy (2008). Effect of dietary fatty acid pattern on growth, body fat composition and antioxidant parameters in broilers. $J$. Anim. Physiol and Anim. Nutr .92(3): $369-76$.

Feldman, B. F., J. G. Zinkl and N.C. Jain (2000). Schalm's veterinary hematology. 5th Edition, Williams and Wilkins, Philadelphia, 21 - 100.

Heady, E. O. and H. R. Jensen (1954). Farm Management Eonomics. Pentice - Hall Inc.Englewood Cliffs,N.J., USA.

Houguo, X. U., Z. Yanjiao, W. Jun, Z. Rantao, M. Kangsen and A. Qinghui (2015). Replacement of fish oil with linseed oil or soybean oil in feeds for japanese seabass, lateolabrax japonicus: Effects on growth performance, immune response, and tissue fatty acid composition. J. world aquaculture society. Vol. 46, No. 4.

Lopez-Ferrer, S., M. D. Baucells, A. C. Barroeta and M. A. Grashorn (2001). N3 enrichment of chicken meat. 1. Use of very long-chain fatty acids in chicken diets and their influence on meat quality: fish oil. Poul. Sci., 80(6):741 - 752.

Malwina, Z., K. Bozena, K. Renata and S. Wioletta (2020). Inclusion of camelina, flax and sunflower seeds in the diets for broiler chickens: apparent digestibility of nutrients, growth performance, health status, and carcass and meat quality traits. Animals 10(2):321.

Masek, T., K. Starcevic, N. Filipovic, Z. Stojevi, D. Brozi, Z. Gottstein and K. Severin (2014). Tissue fatty acid composition and estimated A desaturase activity after castration in chicken broilers fed with linseed or sunflower oil. J. Anim. Physiol. and Anim. Nutr. DQI: 10.1111 /jpn. 12114.

Nguyen, C. V., S. Smulikowska and A. Mieczkowska (2003). Effect of linseed and rapeseed or linseed and rapeseed oil on performance, slaughter yield and fatty acid deposition in edible parts of the carcass in broiler chickens. J.Anim. Feed Sci., 12(2):271 - 288.

NRC, (1994). Nutrient requirements of poultry. 9 th rev. ed. Washington (DC): National Academy Press.

Panda, A. K., K. Sridhar, G. Lavanya, B. Prakash, S. V. Rame Rao and M. V. L. N. RAJU (2015). Growth performance, carcass characteristics, fatty acid composition and sensory attributes of meat of broiler chickens fed diet incorporated with linseed oil. Indian $\mathbf{J}$. Anim. Sci., 85 (12): 1354-1357. 
Rahimi, S., S. Kamran Azad and M. A. Karimi Torshizi (2011). Omega-3 enrichment of broiler meat by using two oil seeds. J. Agr. Sci. Tech. Vol. 13: $353-365$.

Simopoulos, A. P (2009). Evolutionary aspects of the dietary Omega-6: Omega-3 fatty acid ratio: medical Implications. In A balanced Omega6/Omega-3 fatty acid ratio, cholesterol and coronary heart disease.; 100:1 21.

Snedecor, W. G and G. W. Cochran (1982). Statistical Method. 6th Edition. lowa State College Press. lowa, USA.

SPSS (2011). SPSS 11.0 for Windows. SPSS Inc., Chicago. Standardization ministration of china. 2005 . National feed Industry Standards for Enzyme Assays in china.

Starčević, K., T. Mašek, D. Brozić, N. Filipović and Z. Stojević (2014). Growth performance, serum lipids and fatty acid profile of different tissues in chicken broilers fed a diet supplemented with linseed oil during a prolonged fattening period.Vet. Archiv.84 (1): 75 - 84.

Van der Klis, J. D., C. Kwakernaak, A. Jansman and M. Blok (2010). Energy in poultry diets: Adjusted AME or net energy. Proc. Aust. Poult. Sci., Symp. Sydney Aust., 21: 44 - 49.

Wenying, H., M. Lia, J. Wang, Z. Wanga, Y. Huanga and W. Chen ( 2019). On growth performance, nutrient digestibility, blood $\mathbf{T}$ lymphocyte subsets, and cardiac antioxidant status of broilers. Anim. Nutr. 5 (1):68 - 73.

Wongsuthavas, S., S. Terapuntuwat, W. Wongsrikeaw, S. Katawatin, C. Yuangklang and A. C. Beynen (2008). Influence of amount and type of fat deposition, adipocyte count and iodine number of abdominal fat in broiler chickens. J. Anim. Physiol. Anim. Nutr. 92:92 - 98. 
تأثير اضافة زيت الكتان أو زيت دوار الثمس الي العلائق على أداء كتاكيت التسمين

عبد المنعم عبد الحليم الفقى، جمال عبد الستار زناتي، منال كمال أبو النجا، مصطفى أمين برعى مدين

قسم انتاج الدواجن والأسماك - كلية الزراعة - جامعة الدنوفية - مصر ملين

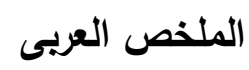

أجريت هذه التجرية في إحدى المزارع التجارية الخاصة بمدينة بركة السبع - محافظة المنوفية - مصر - خلال

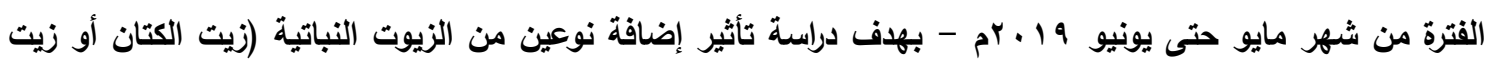

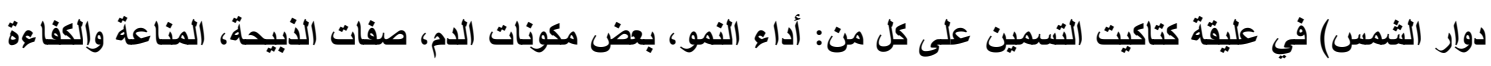

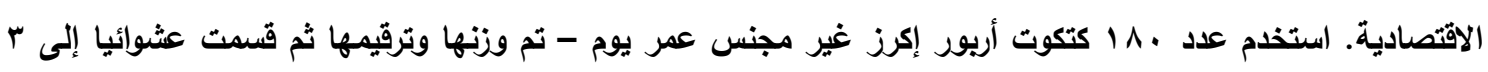

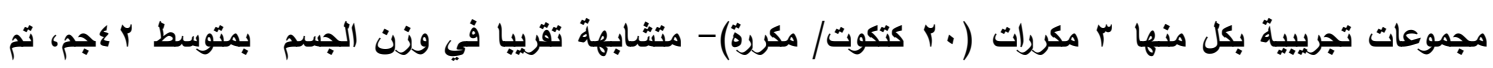

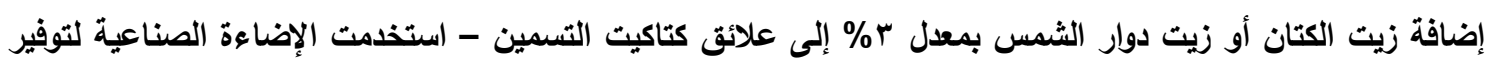

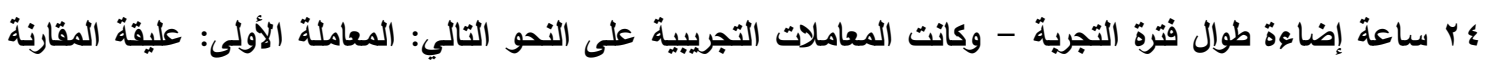

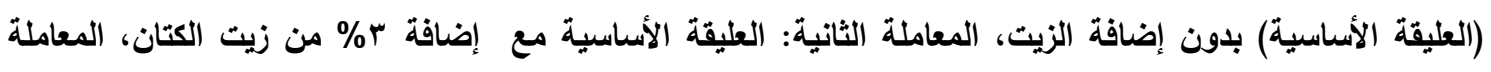

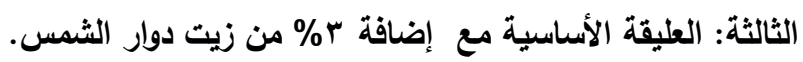

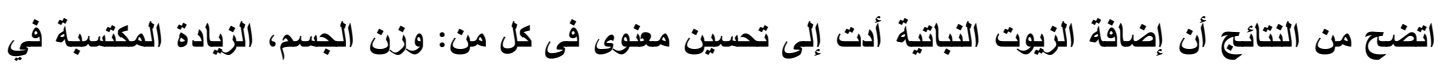

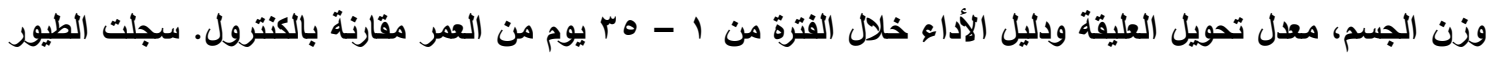

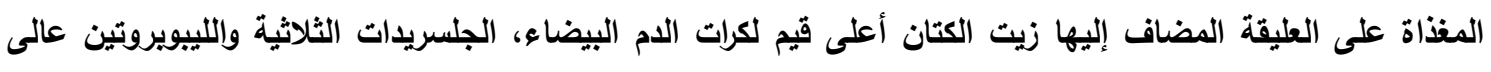

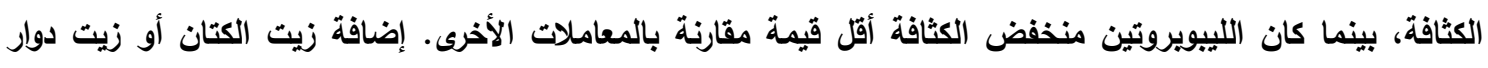

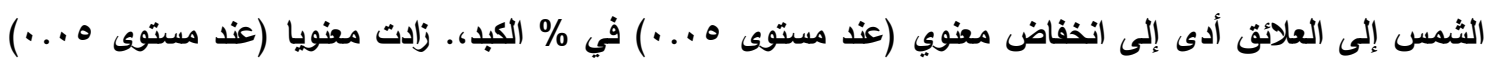

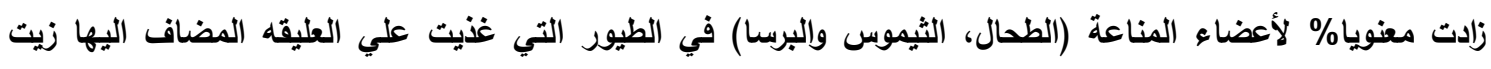

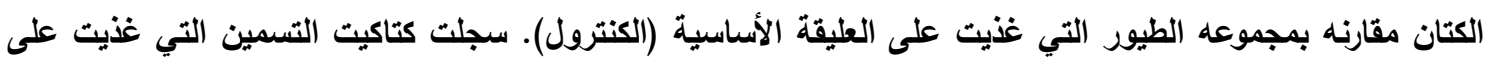

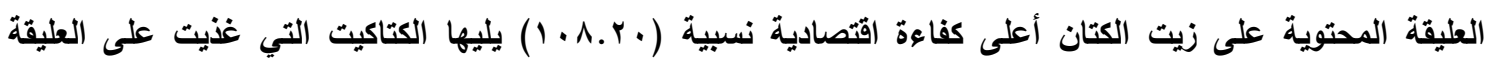

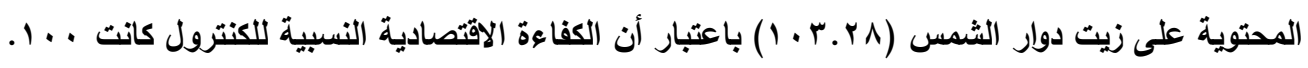


A. A. EL- Fiky, et al.,

يمكن استتتاج أن إضافة ץ\% زيت الكتان إلى علائق كتاكيت التسمين أدي الي تحسين وزن الجسم، معدل تحويل

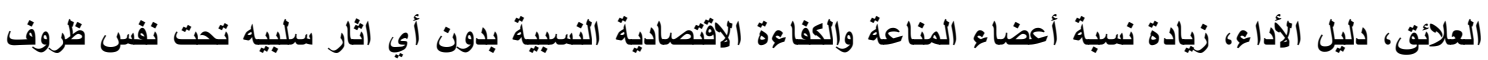

هذه الدراسة.

الكلمات المرشدة : كتاكيت التسمين، زيت الكتان، زيت دوار الثمس، أداء النمو، مكونات الدم، المناعة.

أسماء السادة المحكمين

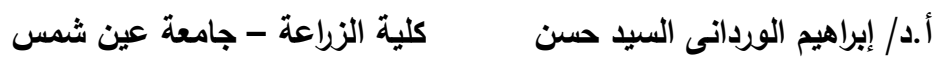

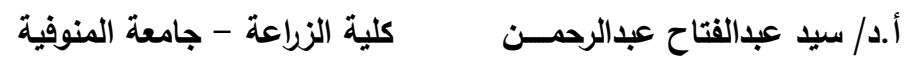

